\title{
Microplastics in freshwater ecosystems: what we know and what we need to know
}

\author{
Martin Wagner ${ }^{1 *}$, Christian Scherer ${ }^{1}$, Diana Alvarez-Muñoz ${ }^{2}$, Nicole Brennholt ${ }^{3}$, Xavier Bourrain ${ }^{4}$, \\ Sebastian Buchinger ${ }^{3}$, Elke Fries ${ }^{5}$, Cécile Grosbois ${ }^{6}$, Jörg Klasmeier ${ }^{7}$, Teresa Marti ${ }^{8}$, Sara Rodriguez-Mozaz², \\ Ralph Urbatzka ${ }^{9}$, A Dick Vethaak ${ }^{10}$, Margrethe Winther-Nielsen ${ }^{11}$ and Georg Reifferscheid ${ }^{3}$
}

\begin{abstract}
Background: While the use of plastic materials has generated huge societal benefits, the 'plastic age' comes with downsides: One issue of emerging concern is the accumulation of plastics in the aquatic environment. Here, so-called microplastics (MP), fragments smaller than $5 \mathrm{~mm}$, are of special concern because they can be ingested throughout the food web more readily than larger particles. Focusing on freshwater MP, we briefly review the state of the science to identify gaps of knowledge and deduce research needs.
\end{abstract}

State of the science: Environmental scientists started investigating marine (micro)plastics in the early 2000s. Today, a wealth of studies demonstrates that MP have ubiquitously permeated the marine ecosystem, including the polar regions and the deep sea. MP ingestion has been documented for an increasing number of marine species.

However, to date, only few studies investigate their biological effects.

The majority of marine plastics are considered to originate from land-based sources, including surface waters. Although they may be important transport pathways of MP, data from freshwater ecosystems is scarce. So far, only few studies provide evidence for the presence of MP in rivers and lakes. Data on MP uptake by freshwater invertebrates and fish is very limited.

Knowledge gaps: While the research on marine MP is more advanced, there are immense gaps of knowledge regarding freshwater MP. Data on their abundance is fragmentary for large and absent for small surface waters. Likewise, relevant sources and the environmental fate remain to be investigated. Data on the biological effects of MP in freshwater species is completely lacking. The accumulation of other freshwater contaminants on MP is of special interest because ingestion might increase the chemical exposure. Again, data is unavailable on this important issue.

Conclusions: MP represent freshwater contaminants of emerging concern. However, to assess the environmental risk associated with MP, comprehensive data on their abundance, fate, sources, and biological effects in freshwater ecosystems are needed. Establishing such data critically depends on a collaborative effort by environmental scientists from diverse disciplines (chemistry, hydrology, ecotoxicology, etc.) and, unsurprisingly, on the allocation of sufficient public funding.

Keywords: Chemistry; Ecotoxicology; Environmental quality; Litter; Microplastics; Monitoring; Plastics; Polymers; Review; Water framework directive

\footnotetext{
* Correspondence: wagner@bio.uni-frankfurt.de

'Department of Aquatic Ecotoxicology, Goethe University Frankfurt am Main,

Max-von-Laue-Str. 13, Frankfurt 60438, Germany

Full list of author information is available at the end of the article
}

\section{它 Springer}

(c) 2014 Wagner et al.; licensee Springer. This is an Open Access article distributed under the terms of the Creative Commons Attribution License (http://creativecommons.org/licenses/by/4.0), which permits unrestricted use, distribution, and reproduction in any medium, provided the original work is properly credited. 


\section{Background}

\section{Microplastics are freshwater contaminants of emerging} concern

Among the multiple human pressures on aquatic ecosystems, the accumulation of plastic debris is one of the most obvious but least studied. While plastics generate remarkable societal benefits [1], there are downsides to our 'plastic age'. Durability, unsustainable use, and inappropriate waste management cause an extensive accumulation of plastics in natural habitats [2]. In the marine environment, plastics of various size classes and origins are ubiquitous and affect numerous species that become entangled in or ingest plastics [3].

Under environmental conditions, larger plastic items degrade to so-called microplastics (MP), fragments typically smaller than $5 \mathrm{~mm}$ in diameter (see Table 1 for further information). Besides these degradation products (secondary MP), MP can also be produced as such (primary MP). For instance, MP are intentionally used as resin pellets (raw material for the production of plastic products) or as ingredient of personal care products (e.g., peelings and shower gels).

MP are of special concern since their bioaccumulation potential increases with decreasing size. MP may be ingested by various organisms ranging from plankton and fish to birds and even mammals, and accumulate throughout the aquatic food web [4]. In addition, plastics contain a multitude of chemical additives [5] and adsorb organic contaminants from the surrounding media [6]. Since these compounds can transfer to organisms upon ingestion, MP act as vectors for other organic pollutants [7] and are, therefore, a source of wildlife exposure to these chemicals $[8,9]$.

Accordingly, MP are considered an emerging global issue by various experts $[10,11]$ and international institutions [12,13]. These concerns and the public interest, however, focus almost exclusively on marine plastic debris. However, we argue that microplastics are also freshwater contaminants of emerging concern. This is supported by three arguments. First, although data is scarce, MP are present in freshwater ecosystems. Second, MP contain and adsorb micropollutants and pathogens. Third, laboratory studies demonstrate that marine organisms ingest MP and suffer adverse effect. While data on freshwater species is scarce, there is no reason to suppose that they remain unaffected. Thus, concerns about the impact of MP on freshwater ecosystems are legitimate and should receive more scientific attention.

\section{State of the science: focus on marine microplastics}

So far, scientific efforts focus on marine MP, and studies on their abundance and effects become increasingly available. Because of its high mobility, plastic debris has practically permeated the global marine environment [14,15], including the polar regions [2], mid-ocean islands [16], and the deep sea [17]. Because of their specific hydrology, the large oceanic gyres are hot spots of plastic pollution (colloquially termed 'garbage patches'), accumulating buoyant plastic debris. Here, the plastic abundance often exceeds that of zooplankton [18-21]. With respect to Europe's regional seas, MP have been reported for the Baltic, North, and Mediterranean Sea [22-25].

Most of the studies investigate neustonic and pelagic MP. However, MP are also present in sediments and have been detected on the shorelines and seafloors of six continents $[15,26,27]$ with typical concentrations ranging from 1 to 100 items $\mathrm{kg}^{-1}$ [28]. A Belgian study reports a maximum of 400 items $\mathrm{kg}^{-1}$ in coastal harbor sediments [29]. Higher concentrations were reported in a Dutch study with 770 and 3,300 items $\mathrm{kg}^{-1}$ dry weight sediment in the Wadden Sea and the Rhine estuary, respectively [30]. Although abundant ubiquitously, the spatial distribution of

Table 1 Classification of environmental (micro)plastics

\begin{tabular}{|c|c|}
\hline Category & Description \\
\hline Classification & $\begin{array}{l}\text { Environmental plastics are a very heterogeneous group of litter that can be characterized by various descriptors. In the literature, they } \\
\text { are frequently stratified according to size, origin, shape, polymer type, and color. So far, there is no common classification system. } \\
\text { Recently, the European MSFD Working Group on Good Environmental Status (WG-GES) provided a 'Monitoring Guidance for Marine } \\
\text { Litter in European Seas' [76], which represents an important step towards a standardized sampling and monitoring of marine microplastics. }\end{array}$ \\
\hline Size & $\begin{array}{l}\text { The WG-GES defines size classes for plastic litter as follows: macroplastics (>25 mm), mesoplastics ( } 5 \text { to } 25 \mathrm{~mm} \text { ), large microplastics } \\
\text { (1 to } 5 \mathrm{~mm}) \text {, and small microplastics }(20 \mu \mathrm{m} \text { to } 1 \mathrm{~mm} \text { ). Accordingly, items smaller than } 20 \mu \mathrm{m} \text { will classify as nanoplastics. }\end{array}$ \\
\hline Origin & $\begin{array}{l}\text { Microplastics can also be categorized according to its origin: Primary microplastics are produced as such, for instance as resin pellets } \\
\text { (raw materials for plastic products) or as additives for personal care products (e.g., shower gels and peelings). Secondary microplastics } \\
\text { are degradation products of larger plastic items, which are broken down by UV radiation and physical abrasion to smaller fragments. }\end{array}$ \\
\hline Polymers & $\begin{array}{l}\text { The polymer type of environmental (micro)plastics can be determined by Fourier transformed infrared spectroscopy (FT-IR) or Raman } \\
\text { spectroscopy. In concordance to global production rates, high- and low-density polyethylene (HD/LD-PE), polyethylene terephthalate } \\
\text { (PET), polypropylene (PP), polystyrene (PS), and polyvinyl chloride (PVC) are the most common polymers found in the environment. In } \\
\text { addition, polyamide fibers (nylon) from fishing gears are frequent. }\end{array}$ \\
\hline Shape & $\begin{array}{l}\text { The shape can be described according to the main categories: fragments (rounded, angular), pellets (cylinders, disks, spherules), } \\
\text { filaments (fibers), and granules [76]. }\end{array}$ \\
\hline
\end{tabular}


MP in the marine environment is very heterogeneous [14]. This might be partly due to differences in methodology [28].

Field reports on detrimental interactions of plastics with biota (e.g., entanglement) are manifold [4]. However, only about a dozen studies have investigated MP uptake and effects under laboratory conditions, including two studies on freshwater species (literature search on ISI Web of Science, search term 'microplastic"', manual filtering). With nine of these papers published since 2012, this is a very recent area of research. The ingestion of MP by marine invertebrates has been demonstrated in the laboratory for a broad spectrum of marine species: zooplankton [31-33], the lugworm Arenicola marina [34], the Blue mussel Mytilus edulis [35-37], and the sandhopper Talitrus saltator [38]. M. edulis is the only invertebrate in which the transfer of MP from the digestive tract to tissue has been studied and documented $[35,36]$.

Data on the effects of MP exposure is limited. For zooplankton, a reduced algal feeding has been observed [31]. MP increased the mortality and decreased the fertility in copepods [32]. In the lugworm, MP reduced the weight and feeding and increased the bioaccumulation of plasticassociated polychlorinated biphenyls (PCBs) [34]. Reduced filtering activity and histological changes as response to inflammation have been reported for M. edulis [36,37], although another study did not find significant effects [35]. In the only study with marine vertebrates, the common goby Pomatoschistus microps was exposed to MP and pyrene [39]. MP delayed the pyrene-induced mortality but induced several toxicity biomarkers. In addition, two recent studies demonstrate the trophic transfer of MP along the marine food web from meso- to macrozooplankton [33] and from mussels to crabs [40].

\section{Discussion}

\section{Presence of microplastics in freshwater ecosystems}

Despite of the wealth of data on marine MP, to date, only a handful of studies investigate MP in a freshwater context. MP have been detected in the surface waters of the Laurentian Great Lakes [41]. The average abundance in the neuston was 43,000 items $\mathrm{km}^{-2}$, with a hotspot near metropolitan areas, which may represent important sources.

Three studies report the occurrence of MP in the sediments of lakes. Zbyszewski and Corcoran [42] found 0 to 34 plastic fragments $\mathrm{m}^{-2}$ on the shorelines of Lake Huron (Canada). Here, MP accumulation may be attributed to the lake's currents and nearby plastic manufacturers. Extending their shoreline monitoring to the Lakes Erie and St. Clair, Zbyszewski et al. [43] report 0.2 to 8 items $\mathrm{m}^{-2}$. Sampling two beaches of Lake Garda (Italy), Imhof et al. [44] found 100 and 1,100 MP items $\mathrm{m}^{-2}$ at the southern and northern shores, respectively. Similar to the Great
Lakes, MP here consisted mainly of low-density polymers (polystyrene (PS), polyethylene (PE), and polypropylene (PP)).

Moore et al. [45] provide the first, non-peer-reviewed report on MP in rivers. In three Californian rivers, they found, on average, 30 to 109 items $\mathrm{m}^{-3}$. The midstream of the Los Angeles River carried 12,000 items $\mathrm{m}^{-3}$ and will discharge $>1$ billion MP items day ${ }^{-1}$ into the Pacific Ocean. Although very limited, this data indicates that rivers transport relevant amounts of MP.

According to a recent study, the same is true for the second largest European rivers: Lechner et al. [46] used stationary driftnets and visual inspection to monitor plastic debris in the Austrian Danube. The authors report approximately 900 (2010) and 50 (2012) plastic items $1,000 \mathrm{~m}^{-3}$ in the size class of 0.5 to $50 \mathrm{~mm}$. In a worst-case scenario, the Danube would discharge $4.2 \mathrm{t}$ plastics day ${ }^{-1}$ and $1,500 \mathrm{t}$ plastics year ${ }^{-1}$ to the Black Sea. The latter is more than the total plastic load of the whole North Atlantic Gyre [47]. Lechner et al. provide first evidence that large rivers transport significant amounts of (micro)plastics and thus contribute substantially to the marine plastics pollution.

Because data on the presence of MP in river sediments is lacking, the Federal Institute of Hydrology and the Goethe University carried out a small, exploratory study with sediments from the rivers Elbe, Mosel, Neckar, and Rhine (Germany). Using density separation and visual inspection, we found 34 to $64 \mathrm{MP}$ items $\mathrm{kg}^{-1}$ dry weight, with the River Rhine containing the highest load. Plastic fragments accounted for $60 \%$ of the total MP; the remaining particles were synthetic fibers (Figure 1). Thus, as is the case for marine and estuarine sediments, river and lake sediments may be sinks for MP, deserving further investigation.

\section{Sources of microplastics}

To date, the sources of marine MP are still not very well characterized. A rough estimation predicts that $70 \%$ to $80 \%$ of marine litter, most of it plastics, originate from inland sources and are emitted by rivers to the oceans [12]. Potential sources include wastewater treatment plants (WWTPs), beach litter, fishery, cargo shipping, and harbors $[12,23,25,29,48]$. Although data is so far unavailable, runoff from industrial plastic production sites may be an additional source. Taken together, most marine studies tentatively refer to inland waters as relevant sources (indeed they are rather transport pathways), while actual data is still scarce.

Inland sources of MP have not been investigated thoroughly. In analogy to the marine systems, major contributors will likely include WWTPs and runoff from urban, agricultural, touristic, and industrial areas, as well as shipping activities. Another potential source is sewage sludge that typically contains more MP than effluents 

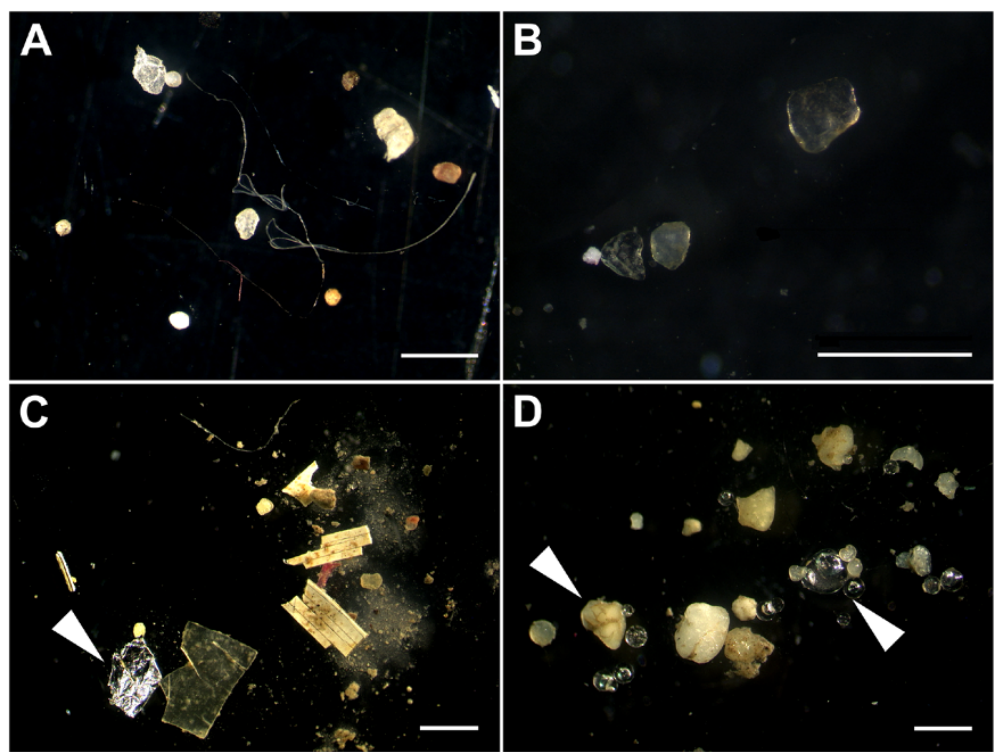

Figure 1 Microplastics in sediments from the rivers Elbe (A), Mosel (B), Neckar (C), and Rhine (D). Note the diverse shapes (filaments, fragments, and spheres) and that not all items are microplastics (e.g., aluminum foil (C) and glass spheres and sand (D), white arrowheads). The white bars represent $1 \mathrm{~mm}$.

[49]. Sewage sludge is still frequently used for landfilling and as fertilizer in agriculture, and surface runoff may transfer MP to rivers and lakes and ultimately river basins and the sea. Washing clothes [26] and personal care products [50] are sources of MP in WWTPs. Since the retention capacity of conventional wastewater treatment processes appears to be limited [14], a characterization of MP emission by WWTPs and other sources is urgently needed to understand where freshwater MP is coming from.

\section{Impact of microplastics on freshwater species}

In a field report, Sanchez et al. [51] provide the only data on MP in freshwater fish so far. They investigated gudgeon (Gobio gobio) caught in 11 French streams and found MP in the digestive tract of $12 \%$ of the fish. Although again very preliminary, this field report shows that freshwater species ingest MP. However, the rate of MP ingestion in different fish species will certainly depend on their feeding strategy. Rosenkranz et al. [52] demonstrate that the water flea Daphnia magna rapidly ingests MP under laboratory conditions. MP (0.02 and 1 $\mathrm{mm}$ ) appear to cross the gut epithelium and accumulate in lipid storage droplets. This is of specific concern because MP infiltrating tissues might induce more severe effects. Imhof et al. [44] report the uptake of MP by annelids (Lumbriculus variegatus), crustaceans (D. magna and Gammarus pulex), ostracods (Notodromas monacha), and gastropods (Potamopyrgus antipodarum). While the available studies demonstrate that a broad spectrum of aquatic taxa is prone to MP ingestion, the toxicological effects remain uninvestigated for freshwater species.

\section{Microplastics as vector for other contaminants}

Due to their large surface-to-volume ratio and chemical composition, MP accumulate waterborne contaminants including metals [53] and persistent, bioaccumulative, and toxic compounds (PBTs) [54]. A review on the relationship between plastic debris and PBTs (e.g., PCBs and DDT) has been published recently [55], and a number of studies exist for polycyclic aromatic hydrocarbons (PAHs) [56-61]. However, there is a lack of information on other important contaminants like pharmaceuticals and endocrine-disrupting compounds (EDCs). Nonylphenol and bisphenol A have been detected in MP $[60,62,63]$. Fries et al. [24] detected various plastic additives in MP, including some well-known EDCs (e.g., phthalates). In addition, Wagner and Oehlmann $[64,65]$ demonstrated that plastics leach EDCs. Since the spectrum of contaminants is different in freshwater and marine systems, the chemical burden of freshwater MP remains to be studied.

The interaction of MP and chemicals has been studied in adsorption-desorption experiments [6,57]. While there is significant complexity in this interaction, MP may act as vector transferring environmental contaminants from water to biota. While different modeling studies arrive at contrasting conclusions [54,66,67], a recent experimental study demonstrates that fish exposed to contaminants sorbed to MP bioaccumulate these compounds and suffer adverse effects (glycogen depletion and histopathological alterations [68]). However, to date, there are too few studies investigating whether MP are indeed vectors that facilitate the transfer of organic contaminants to biota. Because a verification of the 'vector hypothesis' would have major 
ecological implications, it deserves further investigation, especially in a freshwater context.

\section{Microplastics as vector for exotic species and pathogens}

Not only the complex mix of chemicals contained in and sorbed to MP and/or ingestion of MP by biota is a cause for concern but also microorganisms developing biofilms on MP particles. Only very few studies have been conducted on this issue with marine ecosystems being the focal point of interest [69-72]. Zettler et al. [72] described a highly diverse microbial community ('plastisphere') attaching plastic marine debris in the North Atlantic. Several plastisphere members are hydrocarbon-degrading bacteria which may potentially influence plastic debris fragmentation and degradation. But they also found opportunistic (human) pathogens like specific members of the genus Vibrio dominating plastic particles. Therefore, MP can act as a vector for waterborne (human) pathogens influencing the hygienic water quality. The fact that the microbial communities on MP are distinct from surrounding water (only some marine bacteria develop biofilms on microplastic particles (e.g., [71,72])) suggests that MP serve as a kind of new habitat. Until now, the complex interaction between microorganisms/microbial communities as a key player in aquatic ecosystems/food webs and MP, especially in freshwater, is poorly understood and needs to be further investigated.

\section{Microplastics in connection to European water policies}

The issue of (micro)plastics connects to several European water policies. The European Marine Strategy Framework Directive (MSFD, 2008/56/EC) addresses the issue of marine litter, including plastics. Here, MP are covered by Descriptor 10 of Commission Decision 2010/477/EU, which defines the good environmental status of marine waters [73].

In contrast, the Water Framework Directive (WFD, 20/ 60/EC) applying to European inland waters does not specifically refer to plastic litter. However, the Member States have the obligation to monitor anthropogenic pressures. Here, MP are promising candidates, especially because they might act as vectors for a wide range of freshwater contaminants. For instance, MP have been shown to contain the WFD priority substances di(ethylhexyl) phthalate (DEHP), nonylphenol, octylphenol, and PAHs (2008/105/ EC, Annex II).

Several other European Directives relate to the potential sources of freshwater MP, including the Directives on packaging waste (2004/12/EC), waste (2008/98/EC), landfills (1999/31/EC), urban wastewater (91/271/EEC), sewage sludge (86/278/EEC), and ship-source pollution (2005/35/ $\mathrm{EC}$ ). In addition, the Union's chemicals legislation (REACH, 1907/2006/EC) will apply to plastic monomers and additives of relevant production volumes.
In a recent 'Green paper on a European strategy on plastic waste in the environment', the European Commission addresses the issue as part of a wider review of its waste legislation [74]. While the Green Paper focuses on potential mitigation strategies for plastic litter at the source, it also expresses 'particular concern' about MP.

\section{Conclusions}

\section{Knowledge gaps and research needs}

The investigation of (micro)plastics in aquatic environments is a highly dynamic and interdisciplinary area of research covering and bringing together the disciplines of oceanography and hydrology as well as environmental monitoring, modeling, chemistry, and toxicology. In recent years, this collaborative effort advanced our understanding of the environmental impact of MP, especially by providing extensive monitoring data. Ongoing research activities focus, however, almost exclusively on marine MP.

Data on freshwater ecosystems is at best fragmentary if not absent. This lack of knowledge hampers a sciencebased environmental risk assessment of freshwater MP. Such assessment is needed to facilitate a societal and political discussion at national and European levels on the issue, which, depending on the outcome, will result in mitigation measures eventually. For instance, MP could be integrated as descriptor of environmental status in the WFD. However, environmental scientists first need to close the gaps of knowledge with regard to exposure and hazard of freshwater MP and the associated chemicals. Based on the current state of the science, the following research needs emerge (Figure 2):

1. Monitoring the presence of microplastics in freshwater systems. While few studies on large lakes and rivers are available, we have no clear picture on the magnitude of the plastics pollution in surface waters. Generating comprehensive monitoring data on the abundance of freshwater MP is needed to understand their environmental impact.

2. Investigating the sources and fate of freshwater microplastics. Currently, we still do not understand the behavior of MP in aquatic ecosystems. Based on data on their abundance, modeling approaches are needed to identify hotspots and sinks and quantify loads. One important aspect of understanding the environmental fate is also to identify relevant inland sources of MP and determine the fragmentation rates of large plastic debris.

3. Assessing the exposure to microplastics. With evidence coming from marine species, it appears plausible that freshwater organisms will ingest MP, too. However, actual data is scarce. Environmental toxicologists need to determine the intake of MP by freshwater key species. It will be crucial to 


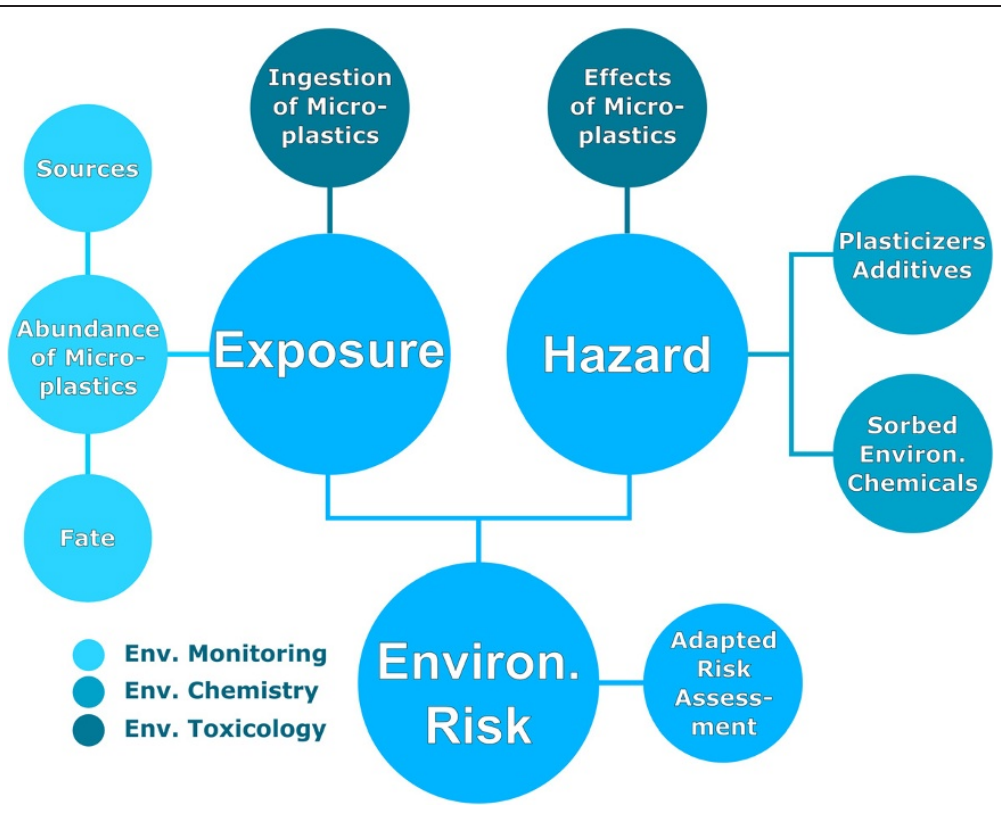

Figure 2 Research aspects with regard to freshwater microplastics. All areas need to be investigated more thoroughly to assess the environmental risk associated with microplastics in freshwater ecosystems.

understand which plastic characteristics (size, material, and shape) promote an uptake and what is the fate of MP in the biota (e.g., excretion, accumulation, and infiltration of tissues). These aspects need to be studied under laboratory conditions and in the field to determine the actual exposure.

4. Evaluating the biological effects of microplastics exposure. Besides abundance and exposure, the question whether MP induce adverse effects in organisms is crucial to determine their environmental hazard. In the absence of effect studies on freshwater species, one can only speculate on potential sensitive endpoints: Ingested plastic fragments may most likely affect the metabolism (starvation due to decreased energy intake) and induce inflammation (when transferring to tissues). Because this is an area of research where the least progress has been made so far, the investigation of MP effects on marine and freshwater species need to be intensified considerably.

5. Understanding the interaction between microplastics and other freshwater contaminants. Plastics itself can contain and release toxic chemicals (e.g., monomers or plastic additives [75]). In addition, they can accumulate environmental chemicals from the surrounding. This may increase the chemical exposure of the ingesting organism and, thus, toxicity. The findings on chemicals associated with marine MP (mostly POPs) cannot be transferred to freshwaters because here the spectrum and concentrations of pollutants is very different. Therefore, it is important to investigate the chemical burden of freshwater MP, including the absorption/desorption kinetics and the transfer of chemicals from plastics to biota.

6. Develop a novel framework for the risk assessment of microplastics. MP can be direct and indirect stressors for the aquatic environment: They are contaminants of emerging concern per se and, in addition, may serve as vectors for invasive species and for other pollutants. To account for that, the classical risk assessment framework needs to be adapted.

For instance, the mixture toxicity of MP-associated compounds and the modulation of the compounds' bioavailability need to be integrated.

There are some challenges in investigating these aspects: To generate commensurable data on the abundance of freshwater MP, harmonized monitoring procedures, including sampling, identification, and characterization, are needed. For that, the 'Monitoring Guidance for Marine Litter in European Seas' developed by the European MSFD Working Group on Good Environmental Status [76] provides an excellent starting point. The separation of MP from the sample materials (sediments or suspended particulate matter) and the confirmation of the plastics' identity to avoid misclassification is still a very resourceconsuming and biased process (e.g., when visually identifying MP in complex samples). Here, sample throughput and accuracy need to be increased. Likewise, we need to improve the capability to detect very small MP in the low micrometer range. Boosting technological innovation in 
the area of MP research (e.g., coupling of microscopy and spectroscopy to identify very small MP) will help meet those challenges.

In conclusion, based on our knowledge on the environmental impact of marine MP, their freshwater counterparts should be considered contaminants of emerging concern. However, there is a considerable lack of knowledge on MP in surface waters worldwide. Data on their presence, sources, and fate is scarce if not absent. The same is true for their chemical burden and biological effects. To enable science-based environmental risk assessment of freshwater MP, it is imperative to initiate coordinated and collaborative research programs that close these gaps of knowledge.

\section{Abbreviations \\ EDCs: endocrine-disrupting compounds; FT-IR: Fourier transformed Infrared spectroscopy; HD/LD-PE: high-/low-density polyethylene; MP: microplastics; MSFD: European Marine Strategy Framework Directive; PAHs: polycyclic aromatic hydrocarbons; PBTs: persistent, bioaccumulative, and toxic compounds; PCBs: perchlorinated biphenyls; PET: polyethylene terephthalate; POPs: persistent organic pollutants; PP: polypropylene; PS: polystyrene; PVC: polyvinyl chloride; WFD: European Water Framework Directive; WWTPS: wastewater treatment plants.}

\section{Competing interests}

The authors declare that they have no competing interests.

\section{Authors' contributions}

MW conceived the manuscript. CS, MW, SB, and GR performed the pilot study on microplastics in river sediments. All authors (MW, CS, DAM, NB, XB, $\mathrm{SB}, \mathrm{EF}, \mathrm{CG}, \mathrm{JK}, \mathrm{TM}, \mathrm{SRM}, \mathrm{RU}, \mathrm{ADV}, \mathrm{MWN}$, and GR) provided substantial input to, read, and approved the final manuscript.

\section{Acknowledgements}

This work was, in part, funded by the German Federal Institute of Hydrology.

\section{Author details}

${ }^{1}$ Department of Aquatic Ecotoxicology, Goethe University Frankfurt am Main, Max-von-Laue-Str. 13, Frankfurt 60438, Germany. ${ }^{2}$ Catalan Institute for Water Research (ICRA), Girona 17003, Spain. ${ }^{3}$ Department Biochemistry and Ecotoxicology, Federal Institute of Hydrology, Koblenz 56002, Germany. ${ }^{4}$ Service Etat des Eaux Evaluation Ecologique, Agence de l'Eau Loire-Bretagne, Ploufragan 22440, France. ${ }^{5}$ Water, Environment and Eco-technologies Division, Bureau de Recherches Géologiques et Minières (BRGM), Orléans 45100, France. ${ }^{6}$ GéoHydrosystèmes Continentaux (GéHCO), Université Francois Rabelais de Tours, Tours 37000, France. ${ }^{7}$ Institute of Environmental Systems Research, Universität Osnabrück, Osnabrück 49074, Germany. ${ }^{8}$ Investigación y Proyectos Medio Ambiente S.L. (IPROMA), Castellón de la Plana 12005, Spain. ${ }^{9}$ Interdisciplinary Centre of Marine and Environmental Research (CIIMAR), Porto 4050-123, Portugal. ${ }^{10}$ Unit Marine and Coastal Systems, Deltares and Institute for Environmental Studies, VU University Amsterdam, Amsterdam 1081, The Netherlands. ${ }^{11}$ Environment and Toxicology, DHI, Hørsholm 2970, Denmark.

Received: 24 April 2014 Accepted: 16 May 2014

Published online: 09 July 2014

\section{References}

1. Andrady AL, Neal MA: Applications and societal benefits of plastics. Philos Trans R Soc Lond B Biol Sci 2009, 364:1977-1984.

2. Barnes DK, Galgani F, Thompson RC, Barlaz M: Accumulation and fragmentation of plastic debris in global environments. Philos Trans $R$ SoC Lond B Biol Sci 2009, 364:1985-1998.

3. Gregory MR: Environmental implications of plastic debris in marine settings- entanglement, ingestion, smothering, hangers-on, hitch-hiking and alien invasions. Philos Trans R Soc Lond B Biol Sci 2009, 364:2013-2025.
4. Wright SL, Thompson RC, Galloway TS: The physical impacts of microplastics on marine organisms: a review. Environ Pollut 2013, 178:483-492.

5. Dekiff JH, Remy D, Klasmeier J, Fries E: Occurrence and spatial distribution of microplastics in sediments from Norderney. Environ Pollut 2014, 186:248-256.

6. Bakir A, Rowland SJ, Thompson RC: Competitive sorption of persistent organic pollutants onto microplastics in the marine environment. Mar Pollut Bull 2012, 64:2782-2789.

7. Zarfl C, Matthies M: Are marine plastic particles transport vectors for organic pollutants to the Arctic? Mar Pollut Bull 2010, 60:1810-1814.

8. Oehlmann J, Schulte-Oehlmann U, Kloas W, Jagnytsch O, Lutz I, Kusk KO, Wollenberger L, Santos EM, Paull GC, Van Look K, Tyler CR: A critical analysis of the biological impacts of plasticizers on wildlife. Philos Trans $R$ Soc Lond B Biol Sci 2009, 364:2047-2062.

9. Teuten EL, Saquing JM, Knappe DR, Barlaz MA, Jonsson S, Bjorn A, Rowland SJ, Thompson RC, Galloway TS, Yamashita R, Ochi D, Watanuki Y, Moore C, Viet PH, Tana TS, Prudente M, Boonyatumanond R, Zakaria MP, Akkhavong K, Ogata Y, Hirai H, Iwasa S, Mizukawa K, Hagino Y, Imamura A, Saha M, Takada $\mathrm{H}$ : Transport and release of chemicals from plastics to the environment and to wildlife. Philos Trans R Soc Lond B Biol Sci 2009, 364:2027-2045.

10. Depledge MH, Galgani F, Panti C, Caliani I, Casini S, Fossi MC: Plastic litter in the sea. Mar Environ Res 2013, 92:279-281.

11. Sutherland WJ, Clout M, Cote IM, Daszak P, Depledge MH, Fellman L, Fleishman E, Garthwaite R, Gibbons DW, De Lurio J, Impey AJ, Lickorish F, Lindenmayer D, Madgwick J, Margerison C, Maynard T, Peck LS, Pretty J, Prior S, Redford KH, Scharlemann JPW, Spalding M, Watkinson AR: A horizon scan of global conservation issues for 2010. Trends Ecol Evol 2010, 25:1-7.

12. GESAMP (IMO/FAO/UNESCO-IOC/UNIDO/WMO/IAEA/UN/UNEP Joint Group of Experts on the Scientific Aspects of Marine Environmental Protection): Proceedings of the GESAMP international workshop on micro-plastic particles as a vector in transporting persistent, bio-accumulating and toxic substances in the oceans. In GESAMP Reports \& Studies. Edited by Bowmer T, Kershaw P. Paris: UNESCO-IOC; 2010. 68 pp.

13. United Nations Environment Programme: UNEP Yearbook: Emerging Issues in Our Global Environment. Nairobi: UNEP Division of Early Warning and Assessment; 2011.

14. Cole M, Lindeque P, Halsband C, Galloway TS: Microplastics as contaminants in the marine environment: a review. Mar Pollut Bull 2011, 62:2588-2597.

15. Ivar do Sul JA, Costa MF: The present and future of microplastic pollution in the marine environment. Environ Pollut 2014, 185:352-364.

16. do Ivar do Sul JA, Costa MF, Barletta M, Cysneiros FJ: Pelagic microplastics around an archipelago of the Equatorial Atlantic. Mar Pollut Bull 2013, 75:305-309.

17. Van Cauwenberghe L, Vanreusel A, Mees J, Janssen CR: Microplastic pollution in deep-sea sediments. Environ Pollut 2013, 182:495-499.

18. Eriksen M, Maximenko N, Thiel M, Cummins A, Lattin G, Wilson S, Hafner J, Zellers A, Rifman S: Plastic pollution in the South Pacific subtropical gyre. Mar Pollut Bull 2013, 68:71-76.

19. Goldstein MC, Titmus AJ, Ford M: Scales of spatial heterogeneity of plastic marine debris in the northeast Pacific Ocean. PLoS One 2013, 8:e80020.

20. Ryan PG: Litter survey detects the South Atlantic 'garbage patch'. Mar Pollut Bull 2014, 79:220-224.

21. Moore CJ, Moore SL, Leecaster MK, Weisberg SB: A comparison of plastic and plankton in the North Pacific Central Gyre. Mar Pollut Bull 2001, 42:1297-1300

22. Collignon A, Hecq JH, Glagani F, Voisin P, Collard F, Goffart A: Neustonic microplastic and zooplankton in the North Western Mediterranean Sea. Mar Pollut Bull 2012, 64:861-864.

23. Dubaish F, Liebezeit G: Suspended microplastics and black carbon particles in the Jade system, southern North Sea. Water Air Soil Pollut 2013, 224:1352.

24. Fries E, Dekiff JH, Willmeyer J, Nuelle MT, Ebert M, Remy D: Identification of polymer types and additives in marine microplastic particles using pyrolysis-GC/MS and scanning electron microscopy. ESPI 2013, 15:1949-1956.

25. Norén F: Small Plastic Particles in Coastal Swedish Waters. Sweden: KIMO; 2007. 
26. Browne MA, Crump P, Niven SJ, Teuten E, Tonkin A, Galloway T, Thompson $\mathrm{R}$ : Accumulation of microplastic on shorelines worldwide: sources and sinks. Environ Sci Technol 2011, 45:9175-9179.

27. Thompson RC, Olsen Y, Mitchell RP, Davis A, Rowland SJ, John AWG, McGonigle D, Russell AE: Lost at sea: where is all the plastic? Science 2004, 304:838

28. Hidalgo-Ruz V, Gutow L, Thompson RC, Thiel M: Microplastics in the marine environment: a review of the methods used for identification and quantification. Environ Sci Technol 2012, 46:3060-3075.

29. Claessens M, De Meester S, Van Landuyt L, De Clerck K, Janssen CR: Occurrence and distribution of microplastics in marine sediments along the Belgian coast. Mar Pollut Bull 2011, 62:2199-2204.

30. Leslie HA, van Velzen MJM, Vethaak AD: Microplastic Survey of the Dutch Environment. Novel Data Set of Microplastics in North Sea Sediments, Treated Wastewater Effluents and Marine Miota. Amsterdam: Institute for Environmental Studies, VU University Amsterdam; 2013

31. Cole M, Lindeque P, Fileman E, Halsband C, Goodhead R, Moger J, Galloway TS: Microplastic ingestion by zooplankton. Environ Sci Technol 2013, 47:6646-6655

32. Lee KW, Shim WJ, Kwon OY, Kang JH: Size-dependent effects of micro polystyrene particles in the marine copepod Tigriopus japonicus. Environ Sci Technol 2013, 47:11278-11283.

33. Setälä $\mathrm{O}$, Fleming-Lehtinen $\mathrm{V}$, Lehtiniemi M: Ingestion and transfer of microplastics in the planktonic food web. Environ Pollut 2014, 185:77-83.

34. Besseling E, Wegner A, Foekema EM, van den Heuvel-Greve MJ, Koelmans AA: Effects of microplastic on fitness and PCB bioaccumulation by the lugworm Arenicola marina (L.). Environ Sci Technol 2013, 47:593-600.

35. Browne MA, Dissanayake A, Galloway TS, Lowe DM, Thompson RC: Ingested microscopic plastic translocates to the circulatory system of the mussel, Mytilus edulis (L.). Environ Sci Technol 2008, 42:5026-5031.

36. von Moos N, Burkhardt-Holm P, Kohler A: Uptake and effects of microplastics on cells and tissue of the blue mussel Mytilus edulis L. after an experimental exposure. Environ Sci Technol 2012, 46:11327-11335.

37. Wegner A, Besseling E, Foekema EM, Kamermans P, Koelmans AA: Effects of nanopolystyrene on the feeding behavior of the blue mussel (Mytilus edulis L.). Environ Toxicol Chem 2012, 31:2490-2497.

38. Ugolini A, Ungherese G, Ciofini M, Lapucci A, Camaiti M: Microplastic debris in sandhoppers. Estuar Coast Shelf Sci 2013, 129:19-22.

39. Oliveira M, Ribeiro A, Hylland K, Guilhermino L: Single and combined effects of microplastics and pyrene on juveniles ( $0+$ group) of the common goby Pomatoschistus microps (Teleostei, Gobiidae). Ecol Indic 2013, 34:641-647.

40. Farrell P, Nelson K: Trophic level transfer of microplastic: Mytilus edulis (L.) to Carcinus maenas (L.). Environ Pollut 2013, 177:1-3.

41. Eriksen M, Mason S, Wilson S, Box C, Zellers A, Edwards W, Farley H, Amato S: Microplastic pollution in the surface waters of the Laurentian Great Lakes. Mar Pollut Bull 2013, 77:177-182.

42. Zbyszewski M, Corcoran PL: Distribution and degradation of fresh water plastic particles along the beaches of Lake Huron, Canada. Water Air Soil Pollut 2011, 220:365-372.

43. Zbyszewski M, Corcoran PL, Hockin A: Comparison of the distribution and degradation of plastic debris along shorelines of the Great Lakes, North America. J Great Lakes Res 2014, 40:288-299.

44. Imhof HK, Ivleva NP, Schmid J, Niessner R, Laforsch C: Contamination of beach sediments of a subalpine lake with microplastic particles. Curr Biol 2013, 23:R867-R868.

45. Moore CJ, Lattin GL, Zellers AF: Working Our Way Upstream: A Snapshot of Land-Based Contributions of Plastic and Other Trash to Coastal Waters and Beaches of Southern California. Long Beach: Algalita Marine Research Foundation; 2005.

46. Lechner A, Keckeis H, Lumesberger-Loisl F, Zens B, Krusch R, Tritthart M, Glas $M$, Schludermann E: The Danube so colourful: a potpourri of plastic litter outnumbers fish larvae in Europe's second largest river. Environ Pollut 2014, 188:177-181

47. Law KL, Moret-Ferguson S, Maximenko NA, Proskurowski G, Peacock EE, Hafner J, Reddy CM: Plastic accumulation in the North Atlantic subtropical gyre. Science 2010, 329:1185-1188.

48. Zubris KA, Richards BK: Synthetic fibers as an indicator of land application of sludge. Environ Pollut 2005, 138:201-211.

49. Leslie HA, Moester M, de Kreuk M, Vethaak AD: Verkennende studie naar lozing van microplastics door rwzi's. (Pilot study on emissions of microplastics from wastewater treatment plants). H2O 2012, 14/15:45-47 (in Dutch).

50. Fendall LS, Sewell MA: Contributing to marine pollution by washing your face: microplastics in facial cleansers. Mar Pollut Bull 2009, 58:1225-1228.

51. Sanchez W, Bender C, Porcher JM: Wild gudgeons (Gobio gobio) from French rivers are contaminated by microplastics: preliminary study and first evidence. Environ Res 2014, 128:98-100.

52. Rosenkranz P, Chaudhry Q, Stone V, Fernandes TF: A comparison of nanoparticle and fine particle uptake by Daphnia magna. Environ Toxicol Chem 2009, 28:2142-2149.

53. Ashton $\mathrm{K}$, Holmes $\mathrm{L}$, Turner A: Association of metals with plastic production pellets in the marine environment. Mar Pollut Bull 2010, 60:2050-2055

54. Koelmans AA, Besseling E, Wegner A, Foekema EM: Plastic as a carrier of POPs to aquatic organisms: a model analysis. Environ Sci Technol 2013, 47:7812-7820.

55. Engler RE: The complex interaction between marine debris and toxic chemicals in the ocean. Environ Sci Technol 2012, 46:12302-12315.

56. Antunes JC, Frias JGL, Micaelo AC, Sobral P: Resin pellets from beaches of the Portuguese coast and adsorbed persistent organic pollutants. Estuar Coast Shelf S 2013, 130:62-69.

57. Bakir A, Rowland SJ, Thompson RC: Enhanced desorption of persistent organic pollutants from microplastics under simulated physiological conditions. Environ Pollut 2013, 185C:16-23.

58. Fisner M, Taniguchi S, Majer AP, Bicego MC, Turra A: Concentration and composition of polycyclic aromatic hydrocarbons (PAHs) in plastic pellets: implications for small-scale diagnostic and environmental monitoring. Mar Pollut Bull 2013, 76:349-354

59. Zarfl C, Fleet D, Fries E, Galgani F, Gerdts G, Hanke G, Matthies M: Microplastics in oceans. Mar Pollut Bull 2011, 62:1589-1591.

60. Fries $E$, Zarfl C: Sorption of polycyclic aromatic hydrocarbons (PAHs) to low and high density polyethylene (PE). Environ Sci Pollut Res Int 2012, 19:1296-1304

61. Rios LM, Moore C, Jones PR: Persistent organic pollutants carried by synthetic polymers in the ocean environment. Mar Pollut Bull 2007, 54:1230-1237.

62. Mato $Y$, Isobe T, Takada H, Kanehiro H, Ohtake C, Kaminuma T: Plastic resin pellets as a transport medium for toxic chemicals in the marine environment. Environ Sci Technol 2001, 35:318-324.

63. Hirai H, Takada H, Ogata Y, Yamashita R, Mizukawa K, Saha M, Kwan C, Moore C, Gray H, Laursen D, Zettler ER, Farrington JW, Reddy CM, Peacock $\mathrm{EE}$, Ward MW: Organic micropollutants in marine plastics debris from the open ocean and remote and urban beaches. Mar Pollut Bull 2011, 62:1683-1692

64. Wagner M, Oehlmann J: Endocrine disruptors in bottled mineral water: total estrogenic burden and migration from plastic bottles. Environ $\mathrm{SC}$ Pollut Res 2009, 16:278-286.

65. Wagner M, Oehlmann J: Endocrine disruptors in bottled mineral water: estrogenic activity in the E-Screen. J Steroid Biochem Mol Biol 2011 127:128-135.

66. Teuten EL, Rowland SJ, Galloway TS, Thompson RC: Potential for plastics to transport hydrophobic contaminants. Environ Sci Technol 2007, 41:7759-7764.

67. Gouin T, Roche N, Lohmann R, Hodges G: A thermodynamic approach for assessing the environmental exposure of chemicals absorbed to microplastic. Environ Sci Technol 2011, 45:1466-1472

68. Rochman CM, Hoh E, Kurobe T, Teh SJ: Ingested plastic transfers hazardous chemicals to fish and induces hepatic stress. Sci Rep 2013, 3:3263.

69. Carson HS, Nerheim MS, Carroll KA, Eriksen M: The plastic-associated microorganisms of the North Pacific Gyre. Mar Pollut Bull 2013, 75:126-132.

70. Harrison JP, Sapp M, Schratzberger M, Osborn AM: Interactions between microorganisms and marine microplastics: a call for research. Mar Technol Soc J 2011, 45:12-20.

71. Harrison JP: The Spectroscopic Detection and Bacterial Colonisation of Synthetic Microplastics in Coastal Marine Sediments. Sheffield: University of Sheffield; 2012

72. Zettler ER, Mincer TJ, Amaral-Zettler LA: Life in the "plastisphere": microbial communities on plastic marine debris. Environ Sci Technol 2013, 47:7137-7146. 
73. Galgani F, Hanke G, Werner S, De Vrees L: Marine litter within the European Marine Strategy Framework Directive. ICES J Mar Sci 2013, 70:1055-1064.

74. European Commission: Green Paper on a European Strategy on Plastic Waste in the Environment. Brussels: European Commission; 2013.

75. Rochman CM: Plastics and priority pollutants: a multiple stressor in aquatic habitats. Environ Sci Technol 2013, 47:2439-2440.

76. MSFD GES Technical Subgroup on Marine Litter (TSG-ML): Monitoring Guidance for Marine Litter in European Seas, Draft report. Brussels: European Commission; 2013

doi:10.1186/s12302-014-0012-7

Cite this article as: Wagner et al:: Microplastics in freshwater ecosystems: what we know and what we need to know. Environmental Sciences Europe 2014 26:12.

\section{Submit your manuscript to a SpringerOpen ${ }^{\circ}$} journal and benefit from:

- Convenient online submission

- Rigorous peer review

- Immediate publication on acceptance

- Open access: articles freely available online

- High visibility within the field

- Retaining the copyright to your article 